\title{
A Critical Analysis of Halal Marketing in Malaysia's Multi-Level Marketing (MLM) Industry
}

Shamsiah Yaakob ${ }^{1 *}$, Betania Kartika ${ }^{1}$, Mohammad Aizat Jamaludin ${ }^{1}$, Mohamad Afiq Razali ${ }^{1}$, Firdaus Fanny Putera Perdana ${ }^{1}$

${ }^{1}$ International Institute for Halal Research and Training, Level 3, KICT Building, International Islamic University Malaysia, Jalan Gombak, 53100 Kuala Lumpur, Malaysia.

*Corresponding author: Shamsiah Yaakob, International Institute for Halal Research and Training (INHART), Level 3, KICT Building, International Islamic University Malaysia (IIUM), Jalan Gombak, 53100, Selangor, Malaysia; shamsiahyaakob77@gmail.com

\begin{abstract}
The concept of Halalan Toyyiban is very important in Muslims' lives in their servitude to Allah. The business itself is broken down into many different kinds, one of those which has become the trend nowadays is Multi-Level Marketing (MLM). MLM business is a business model that involves selling and recruitment of new distributors into the company. Multi-Level Marketing is seen to be good as it helps many people to achieve their dreams, the contrary, it is observed as a medium of cheating. With its players reaching 2 million in Malaysia since its establishment in the early 1990s, MLM's presence in the business industry should not be taken lightly. This research attempts to analyse the current MLM system and its factors that can be categorised as Halalan Toyyiban, as well as the factors which lead to the destruction. This factor includes the system itself, manufacturing, the distribution channels, the after-sales service, and the long-run vision of the company. By doing this, it is aimed that the doubtful (Syubhah) or even the impermissible (Haram) practices of MLM can be eliminated and abstained by the Muslim players, and it is expected that better MLM companies can be established, using proper S.O.P and guidelines. The purposes of the research are gained through a qualitative approach from the library research and interviews.

Keywords: Multi-Level Marketing; Halalan Toyyiban; Halal Industry; Syubhah; Haram practice; Opportunity; Ethic

Received: $18^{\text {th }}$ February 2020

Accepted: $22^{\text {nd }}$ August 2020

Citation: Yaakob S, Kartika B, Jamaludin MA et al. A critical analysis of halal marketing in Malaysia's Multi-Level Marketing (MLM) industry. J Halal Ind Serv 2020; 3(1): a0000119.

Published Online: $22^{\text {nd }}$ September 2020 https://doi.org/10.36877/jhis.a0000119
\end{abstract}

\section{Introduction}

Marketing is the backbone of any business operation. The achievement of key performance index (KPI) is based on the success of marketing. In global economic trends today, industry 4.0 marketing shows an important role to enhance the business opportunity (Vassileva, 2017). Goldsmith (2004) stated the current and future trends in marketing study are based on four main topics that are globalisation, technology, personalisation, and integration in the business world. There are three areas in marketing which are marketing management, marketing research, and marketing theory (Day \& Wensley, 1983). The main arguments are the effects of globalisation, technology, and non-free personalities, but they 
interact to influence the way marketing will be practised and taught within the next decade. The scenario of marketing business basically can be approved in two types of practices that are single-level marketing (trading) and pyramid system (Frambach \& Schillewaert, 2002).

In Malaysia, Multi-Level Marketing (referred to as MLM) is one of the rapid growing industries. However, the conventional practice of marketing is doubted to be fair to the people. Therefore, the Islamic principle stresses justice should be implemented to overcome the injustice practices in this field. The application of Halal marketing is still not established and there is less discussion in literature from the Shariah perspective (Ahmed et al., 2014; Aziz \& Chok, 2013; Islam \& Chandrasekaran, 2013). Many MLM companies in Malaysia still practise the hit and run concept even though MLM rules and guidelines have been established (Harden, 1987). In 2017, a total of 1993 companies applied for a license under direct sales, out of this number, around 1501 to 1545 companies were doing health products, food, cosmetic and pharmaceutical (Kiaw \& Run, 2007).

The application of conventional marketing is based on 4P's Model (Product, Price, Place and People) (Constantinides, 2002). According to Act 500 (direct selling deed and antipyramid scheme 1993), MLM is a "door-to-door sale" which means the sale of goods or services is carried out in the way that members get members to sell products such as one-toone approach or through online. Several issues related to ethics and value of marketing such as fraud, usury (riba), oppression (the up line gaining more for less effort) and misunderstanding have been practised in operation and marketing department which do not follow the Shariah guidelines (Abdul Cader, 2015).

Shariah Compliant Marketing should be implemented in Halal Industry based on Shariah guidelines (Alserhan, 2015). Lack of information on the operation of companies would create many problems, such as the case of Pak Man Telo and money laundering activities in MLM business. These cases show that the marketing methods they used in MLM were the traditional ones, which are one-to-one approach, online marketing and systematic data sets and also every data obtained was controlled by a computerised system of Pak Man Telo or they called it the Ponzi scheme; money was collected from the downlines, and they were promised to be paid double within 90 days by purchasing foreign postal coupons. This investment was successful in the beginning but then failed and was unable to pay to later investors. By doing so, it created a huge problem, which caused a loss for the stakeholders.

Each company is responsible to understand the customers' needs and demands for competitive advantage in the Halal industry (Bohari et al., 2017). The customers will support the company to maintain the value and satisfied customers will design the future market offered based on customers' needs. Marketing can help a company to work and survive in this complex, changing and turbulent environment. The main objective of marketing is to maintain customer satisfaction and create reasonable profit for the company (Shamsudin \& Rahman, 2014). However, the marketing process must be Halal that is in line with Islamic principles. 
Just like other aspects of life, Islam promotes Halal in everything (Saeed, et al. 2001) including business. Shariah provides guidelines on how businesses need to be promoted in accordance with Islamic ethical codes. So, the effect of global halal marketing increases the speed and the accuracy of marketing decisions and the amount of information used (IzberkBilgin \& Nakata, 2016). It requires the conventional marketing to incorporate Shariah compliance into marketing activities (Abdullah \& Ahmad, 2010). The increase of the knowledge of stakeholders on Islamic marketing (Abuznaid, 2020) establishes more qualified commission and enhances the profitability of the company according to Shariah (Tameme \& Asutay, 2012).

\section{Disucussion}

\section{An Overview of Multi-Level Marketing Industry}

In Malaysia, MLM was established in the past thirty years. According to the Ministry of Domestic Trade, one hundred sixty-seven companies actively and legally run MLM businesses (Kiaw \& Run, 2007), they practise the pyramid system where members will find new members and gain a bonus as a profit paid in an oppressive manner (Constantin, 2009). MLM is a method of sales promotion in which a commission is paid not only to the seller responsible for making the sale but also to several levels of sellers that are responsible for distributing knowledge of the product to the seller making the current sale (Siahaan et al., 2014). MLM companies sell and promote health products, food and pharmaceutical, skincare and household products (Kiaw \& Run, 2007). Table 1 shows the system of Multi-Level Marketing pay-out calculation using a system symbol on selling products and services (Taylor, 2000).

Table 1. System Symbol in Multi-Level Marketing.

\begin{tabular}{|l|l|l|}
\hline NO & \multicolumn{1}{|c|}{ SYSTEM SYMBOL } & \multicolumn{1}{c|}{ EXPLANATION } \\
\hline 1 & PPS's & $\begin{array}{l}\text { (wherein no products are offered) and product-based } \\
\text { pyramid schemes (PPS's), operating as MLMs. They are } \\
\text { now appearing by the hundreds on the internet and } \\
\text { established MLM companies are expanding into overseas } \\
\text { markets }\end{array}$ \\
\hline 2 & FTC & $\begin{array}{l}\text { concentrate on the commissions you could earn just for } \\
\text { recruiting new distributors and which (2) generally ignore } \\
\text { the marketing and selling of products and services }\end{array}$ \\
\hline 3 & RVE-EHI & $\begin{array}{l}\text { RVE-compensation systems lead to extreme horizontal } \\
\text { inequality } \\
\text { EHI-in payout over the entire network of distributors-huge } \\
\text { payouts to a tiny percentage of participants, while the vast } \\
\text { majority wind up losing the money and effort they invested } \\
\text { over a period of time }\end{array}$ \\
\hline
\end{tabular}


Tapp \& Spotswood (2013) started the 4P's reconfiguring the social marketing mix as a tool in MLM activities which can be implemented in Halal Marketing. Marketing Mix 4P's which includes Price, Product, Place and Promotion is basic marketing in a managerial approach (McCharty, 1965).

Besides, the elements of 4P's in social marketing have been stretched beyond the breaking point. Originally, 4P's were designed for social marketing mixes that contained products and prices. 4P's are no longer fit in an age where social marketing interventions are so wide-ranging (Tarmudi, 2009). For example, the number of Muslims in Malaysia is $16,581,000$ people and they are very concerned about Halal in each aspect of life (Baharuddin et al., 2015). Besides, Goi (2009) provided an idea of marketing principles to the marketers which can be used as tools to assist them in pursuing their marketing objectives especially in incorporating Halal elements into their business.

Furthermore, Constantinides (2002) added the 4P's web-marketing can be a mixed model to enhance the marketing strategy. Electronic commerce such as social media like Instagram, Facebook, Twitter and YouTube research and applications are 4P's marketing mix model. Halal Marketing framework can be proposed and applied as a traditional and online marketing system as assurance where there is no doubt in marketing activities. Table 2 shows the different concepts of 4P's.

Table 2. Different concepts of 4P's.

\begin{tabular}{|l|l|l|}
\hline \multicolumn{1}{|c|}{ 4P's } & \multicolumn{1}{|c|}{ TRADITIONAL } & \multicolumn{1}{|c|}{ SHARIAH MARKETING } \\
\hline Product & $\begin{array}{l}\text { Most products used for selling to } \\
\text { Multi-Level Marketing company do } \\
\text { not necessarily implement Halal } \\
\text { certification. }\end{array}$ & $\begin{array}{l}\text { All products in Multi-Level } \\
\text { Marketing have Halal certification. } \\
\text { The products must be Halalan } \\
\text { Toyyiban. }\end{array}$ \\
\hline Place & $\begin{array}{l}\text { Office or centre of sale can open } \\
\text { anywhere, no thoughts about } \\
\text { cleanliness. }\end{array}$ & $\begin{array}{l}\text { Office or centre of sale must be a } \\
\text { clean place, which does not have any } \\
\text { non-halal product sold in the } \\
\text { surrounding area. }\end{array}$ \\
\hline Promotion & $\begin{array}{l}\text { Does not follow ethic and value in its } \\
\text { explanation to members. The focus is } \\
\text { only about the high quantity of sale. }\end{array}$ & $\begin{array}{l}\text { Always give the right explanation to } \\
\text { the members, no pressure to achieve } \\
\text { selling performance. }\end{array}$ \\
\hline Price & $\begin{array}{l}\text { The agreement in the selling of product } \\
\text { or services is not based on the Islamic } \\
\text { entity. The focus is on high profit. }\end{array}$ & $\begin{array}{l}\text { Follow Islamic guidelines. Always } \\
\text { do the right calculation to avoid } \\
\text { unlawful interest. }\end{array}$ \\
\hline
\end{tabular}




\section{Pyramid scheme}

The phenomenon known as multi-level or pyramid sales plans first emerged in the mid-1960s. The appeal is the time-honoured, great American dream of opportunity for the little guy to escape from mediocrity. The "plan" is presented as his chance to be his own boss, in his own business, making untold profits for little or no work (Ella, 1973).

MLM schemes designed by companies do not give justice to agents or members for high bonuses or commissions. Agents get more when they can create a pyramid group underneath. The more participants we earn, the more revenue we will generate. This Pyramid scheme shows that agents who acquire members of the public will receive bonuses, commissions and facilities without hard work. This is where oppression and injustice occur during unbalanced marketing. Many deals with scams involve excessive pricing and profit for a marketed product (Shyam, 2017).

\section{Marketing plan}

Payment methods in MLM companies are distributed by percentage (Albaum \& Peterson, 2011). Marketing plans created and stored in the data system by auto-pay can be misleading and invisible in the marketing plan. Disclosure and application of good values in a presentation or even a defined marketing plan must have high integrity and value to ensure that lies and deception do not occur (Bloch, 1996).

\section{Traditional structure}

This is an old payment method in MLM where distributors can recruit as many people as possible without a layout structure. The traditional system involves a lot of recruitment to generate more sales and make more profit. This method enables distributors to appoint multiple agents to ensure that the products being marketed are high in sales and commissions are also high. This traditional system is safer and does not involve high risk where the distributor or agent is clear with the marketing plan set by the company. Here, all shareholders will be given training as well as knowledge products to avoid confusion and inaccurate calculations (Sparks \& Schenk, 2001).

\section{Binary system}

This is a type of marketing plan in which couples need to be created for the distributor to make a profit. It has a heating period in the system. A binary system is a bonus payment system that involves the left and right sides of the bonus calculated and paid according to the left and right calculations (Daduya et al., 2016). In the estimation of bonus payments through this binary system according to Halal marketing, it is not legally Halal and illegal. Referring 
to this SOP, JAKIM binary system does not recognise this due to doubts regarding the calculation of the profit and payment of the bonus.

\section{Muslim Friendly}

Muslim Friendly is a business activity carried out under Islamic law and consumer interests. The term is used to show that the business is fulfilling the major needs of Muslims when doing business.

\section{Guidelines on Islamic Marketing}

Islamic marketing is the wisdom of satisfying the needs of customers through the good conduct of delivering Halal, wholesome, pure and lawful products and services with the mutual consent of both seller and buyer for achieving material and spiritual well-being in the world here and hereafter and making consumers aware of it through the good conduct of marketers and ethical advertising (Arham, 2010; Antara, et al., (2016). In al-Quran, Allah SWT says: "Then eat of what Allah SWT has provided for you which is lawful and good. And be grateful for the favour of Allah SWT, if it is indeed Him that you worship" (al-Quran, 16:114). The al-Quran also mentions: "O you who believe! Eat not Riba doubled and multiplied, but fear Allah SWT that you may be successful" (al-Quran, 2:130). Munadi \& Iswanto, (2020) quoated a hadith by 'Abdullah ibn 'Umar who narrated that the Prophet Muhammad PBUH, said: "Pay the labourer his wages before his sweat dries" (Saheeh Ibn Maajah, 2443).

The Principles of Islamic marketing fill a gap in international business literature covering the aspects and values of Islamic business thought. They provide a framework and practical perspectives for understanding and implementing the Islamic marketing code of conduct (Alserhan, 2015). Halal marketing in Islamic marketing MLM will give stakeholders, marketers, advertisers (Purnama \& Safira, 2017), staff and members the knowledge to understand all marketing strategies and marketing plans clearly without fraud.

\section{$4 P$ 's in Islamic marketing}

There are differences between conventional and Islamic marketing. They are as follows:

\section{Product}

Products at a conventional marketing company will usually produce the maximum profit at a low cost. Sometimes by looking at the product, we are sceptical of the quality of the product. Presentations on the product reflect the quality of the product, as well as the content that is usually in minimum quantity, and the quality of the product is different each time it is supplied. The price of a product also varies according to the suitability of the product. In MLM the price placed is too high and unreasonable. This indicates that there is no adequate and accurate planning for pricing due to inexperience in dealing with 
price fluctuations and market inflation. As a result, the price of the product is not set correctly. The owner then realises this and will then do some trick on the product to get the profit margin he wants. Good profit margins for food and beverage products are usually around $30-40 \%$ while on groceries, margins are usually between $25-30 \%$. Good marketing companies usually set margins at $50-70 \%$ so that more profits can be achieved. This is to ensure a good profit margin. Product owners can quickly lower prices when there is more competition in the market. The company will make some changes and adjustments to the product to make it look more attractive and more expensive so they can earn more profit. Islam has set the general rule that the product cannot be marked up too much for the price. There are two opinions; first, the profit margin should not exceed $200 \%$ (Jawaid, 2010) and the second, any price is reasonable as long as there is an agreement between the two parties.

\section{People}

Islam believes in getting the right people for the right purposes. People stand as an essential element in Islamic Marketing. By putting prophet Muhammad PBUH as the anchor in trade by Siti Khadijah Khuwailid (the prophet's wife), with his character of amanah (honest), siddiq (truthful), tabligh (conveying) and fatonah (intelligent), the trade by Siti Khadijah had gained profit many times fold and the reasons for these successes were related to prophet Muhammad's PBUH excellent characteristics.

According to Sahih Muslim, Prophet Muhammad PBUH was a trustworthy and honest to the extent that when he was asked the cost price of the item, he would say it. This is the reason why Khadijah's business was successful when Prophet Muhammad PBUH anchored it.

\section{Place}

In determining the place of business of a marketing site company, it is very important to determine that the business is operating systematically and adhering to Shariah. Determining the place of business is whether the surrounding area sells non-halal goods or non-halal food. This will affect Islamic customers who are concerned about the business environment and even mistakenly choosing the right place can affect their business performance.

\section{Promotion}

Promotions play an important role in introducing products. The ethics of promotion are important to be within Shariah limits. There are different types of promotions in product marketing, including through billboards, social media, television, radio and more. The ethics of the promotion are to inform the product in its entirety without any deception and to conceal the contents of the product, for example, the product that uses non-legal 
material, but which is concealed and causes fraud on the product. Great promotions can increase sales by large quantities and bring huge returns to the company. Promotions that use sexy female models are unethical and will have a devastating impact on the company's reputation. In the promotion, one must consider Shariah-compliance so that every promotion carried out will have a good effect on the user.

\section{Ethics of Multi-level Marketing Industry}

A pure value-based marketer must be in the spiritual conduct not to commit a breach of ethics in the marketing exercise (Tybout \& Zaltman, 1974). Halal marketing ethics from an Islamic perspective identify the salient features of the Islamic framework of marketing ethics. It highlights the capabilities and strengths of this framework in creating and sustaining a strong ethical marketing culture (Massey et al., 2013). In Multi-Level Marketing industry, the Islamic framework of ethics, self-motivation and value will give an impact of economic growth on industries and employees (Saeed \& Mukhtar, 2001; Rahman et al., 2016).

Based on the literature review conducted, the researchers found gaps, which mark the doubts on the Halal status of MLM marketing activities. A study is conducted to identify the essential Halal marketing strategies in the MLM company.

\section{Law and Fatwa Related to Multi-Level Marketing}

According to JAKIM (2013), Multi-Level Marketing direct sales business guide according to Shariah 21, MLM companies that have the following features are likely to be involved in either haram (forbidden) or syubha (doubtful) transactions.

\section{Elements of the pyramid scheme under law \& regulation by Endrew Bloomenthal}

a) The scheme involves either a degree of maysir or qimar using money game. Newly recruited downlines will lose their participation fee if they cannot find other people to join the scheme.

b) No written agreement between the company and the participants.

c) The scheme only focuses on recruitment, rather than selling products that are beneficial to society.

d) The main income of the company is from the participation fees paid by the downline, rather than from the revenue of the products sold.

e) Participants must purchase a minimum order or certain goods specified by the company or pay a minimum sum (regularly) to enjoy the bonus or other benefits arising from downline or personal sales. 
f) Participants must implement "inventory front-loading”. This is where the MLM company requires participants "to purchase an unreasonable amount of inventory that cannot realistically be resold and/or used within a reasonable amount of time" (Duriat, 2014).

g) Membership rank can be bought (with money). In an MLM business, members are promoted based on their working experience in generating sales or training the downlines.

h) A rigid and unfair reward system based on the hierarchical structure and there is a prohibition from a level-entry participant to earn more than the upline although the former has worked harder to get more sales than the latter.

i) No refund or buy-back policy and participants cannot withdraw from this scheme.

Elements of deception, manipulation, exploitation in the marketing plan and incentive scheme

a) No fair dealing in the management of dealing with marketing and consumers or members do not care about the right ethics, what is often the case is a one-sided advantage that the MLM company only has. Hard-working members or consumers are paid just as much, even payments that do not match up to network marketing.

\section{Elements of coercion}

According to Gaski (1986), the elements of coercion are described as:

a) Hard selling that involves a degree of force undesired by the consumers.

b) Insufficient time is given to consumers to evaluate the product after an explanation is given by the sellers.

c) Participants are not given the choice on the type and quantity of products to buy and they can only buy in fixed packages.

Elements of wastage

a) A few participants may buy the goods in large quantities with wholesale prices hoping to profit by selling at the retail process, but they do not have a credible strategic business plan.

b) Purchase of goods is unrealistic i.e. not based on actual consumption and capability of the participants to sell them. If those products cannot be sold, they may have to be thrown away if they are perishable, or the participant may have problems returning the goods to the company as there is no clear refund policy.

c) The promise of fixed rewards even without effort. 
d) Any MLM company that promises fixed rewards either in the form of commission or bonus without any effort is repugnant to Shariah principles as this contains an element of riba.

e) The author would equate this as the absence of khiyar. In a real business transaction, contracting parties have the option of rescinding or terminating the contract in the absence of certain conditions.

\section{Conclusion}

There are many types of MLM companies with many different structures and benefits. There are different opinions and interpretations of the benefits of each type. It solely depends on the thinking of the founding fathers of the companies who are mainly non-Muslims. From the research done, it was found that it is rather hard for the research to dictate whether a company is to be called Shariah Compliant or not. This is because there are numerous sections of activities that one must consider to recognise something as Shariah-compliant. It could be easier to do so in banking and food industries, but, an MLM industry is huge as the process involves manufacturing, knowledge management (Shaw et al., 2001), leadership (Graebner, 2004), internal (Varey \& Lewis, 2000) and external marketing, long-run vision, and purpose of the companies. To make it worse, the majority of the MLM companies in Malaysia are not owned by Muslims. The purpose of existence is usually merely to make money, lead a lucrative life and without the intention of serving God and Islamic purposes.

Therefore, it is not suitable to measure these Multi-Level Marketing companies on their Islamic practices when they are not Muslims in the first place. For that reason, to regard certain businesses as being Shariah Compliant, the founders of the companies must be Muslims, and only then, it is understandable and imposable for them to follow the Shariah (Abdullah \& Ahmad, 2010) It is hoped that the Muslims would understand this situation and strive to make an MLM company that can be of international level and at par with the preexisting MLM companies. Therefore, it is concluded in this paper that such existing companies are eligible to be acknowledged as 'Muslim-friendly' MLM.

\section{Conflict of Interest}

We declare that we have no conflict of interest.

\section{Reference}

Abdul Cader, A. (2015). Islamic challenges to advertising: a Saudi Arabian perspective. Journal of Islamic Marketing, 6(2), $166-187$.

Abdullah, K., \& Ahmad, M. I. (2010). Compliance to Islamic marketing practices among businesses in Malaysia. Journal of Islamic Marketing, 1(3), 286-297.

Abuznaid, S. A. (2020). Islamic marketing and Muslim consumers' behavior, Asian Journal of Social Science Studies, 5(1), $10-19$. 
Ahmed, M. U., Kristal, M. M., \& Pagell, M. (2014). Impact of operational and marketing capabilities on firm performance: Evidence from economic growth and downturns. International Journal of Production Economics, 154, 59-71.

Albaum, G., \& Peterson, R. A. (2011). Multilevel (network) marketing: An objective view. The Marketing Review, 11(4), 347-361.

Alserhan, B. A. (2015). The Principles of Islamic Marketing. England: Gower Publishing Limited.

Antara, P. M., Musa, R., \& Hassan, F. (2016). Bridging Islamic financial literacy and halal literacy: The way forward in halal ecosystem. Procedia Economics and Finance, 37, 196-202.

Arham, M. (2010). Islamic perspectives on marketing. Journal of Islamic Marketing, 1(2), 149-164.

Aziz, Y. A., \& Chok, N. V. (2013). The role of Halal awareness, Halal certification, and marketing components in determining Halal purchase intention among non-Muslims in Malaysia: A structural equation modeling approach. Journal of International Food \& Agribusiness Marketing, 25(1), 1-23.

Baharuddin, K., Kassim, N. A., Nordin, S. K., \& Buyong, S. Z. (2015). Understanding the halal concept and the importance of information on halal food business needed by potential Malaysian entrepreneurs. International Journal of Academic Research in Business and Social Sciences, 5(2), 170.

Bloch, B. (1996). Multilevel marketing: What's the catch. Journal of Consumer Marketing, 13(4), 18-26.

Bohari, A. M., Hin, C. W., \& Fuad, N. (2017). The competitiveness of halal food industry in Malaysia: A SWOT-ICT analysis. Geografia-Malaysian Journal of Society and Space, 9(1).

Constantin, C. (2009). Multi-level marketing-a tool of relationship marketing. Bulletin of the Transilvania University of Brasov. Economic Sciences. Series V, 2, 31.

Constantinides, E. (2002). The 4S web-marketing mix model. Electronic commerce research and applications, 1(1), 57-76.

Daduya, M. A., Domingo, J. L., Redondo, P. V., \& Supnet, R. K (2016). Binary Compensation Plan of Existing Multilevel Network Marketing Organizations. Retrieved on May 10, 2020 from https://www.academia.edu/26248205/Binary_Compensation_Plan_of_Existing_Multilevel_Network_Marketing_Org anizations

Day, G. S., \& Wensley, R. (1983). Marketing theory with a strategic orientation. Journal of marketing, 47(4), 79-89.

Duriat, F. B. M. (2014). Multi-Level Marketing in Islam \& Case Study of Young Living in Singapore [PDF file]. Retrieved from https://www.maybank2u.com.my/iwov-resources/islamic-my/document/my/en/islamic/scoe/knowledgecentre/research-paper/Multi-Level-Marketing-In-Islam.pdf

Ella, V. G. (1973). Multi-level or pyramid sales systems: Fraud or free enterprise. SDL Rev., 18, 358.

Frambach, R. T., \& Schillewaert, N. (2002). Organizational innovation adoption: A multi-level framework of determinants and opportunities for future research. Journal of Business Research, 55(2), 163-176.

Gaski, J. F. (1986). Interrelations among a channel entity's power sources: Impact of the exercise of reward and coercion on expert, referent, and legitimate power sources. Journal of marketing Research, 23(1), 62-77.

Goi, C. L. (2009). A review of marketing mix: 4Ps or More. International Journal of Marketing Studies, 1(1), 2.

Goldsmith, R. E. (2004). Current and future trends in marketing and their implications for the discipline. Journal of Marketing Theory and Practice, 12(4), 10-17.

Graebner, M. E. (2004). Momentum and serendipity: How acquired leaders create value in the integration of technology firms. Strategic Management Journal, 25(8-9), 751-777.

Harden, D. B. (1987). Glass of the caesars [Exhibition].

Islam, T., \& Chandrasekaran, U. (2013). Halal marketing: Growing the pie. International Journal of Management Research 
and Reviews, 3(12), 3938.

Izberk-Bilgin, E., \& Nakata, C. C. (2016). A new look at faith-based marketing: The global halal market. Business Horizons, 59(3), 285-292.

Jawaid, S. T. (2010). Inward foreign direct investment and aggregate imports: time series evidence from Pakistan. International Economics \& Finance Journal, 5(1-2), 33-43.

JAKIM. (2013). Garis panduan perniagaan jualan langsung secara pemasaran berbilang tingkat (Multi-Level Marketing) mengikut Shariah. Retrieved on 10 May 2020. http://www.islam.gov.my/images/garispanduan/garis_panduan_mlm.pdf

Kiaw, C. O. S. \& Run, E. C. D. (2007). Why Malaysians Join and Stay on in a Multi-Level Marketing Company. ICFAI Journal of Services Marketing, 5(4), 37-52.

Massey, G. R., S. Waller, D., Z. Wang, P., et al. (2013). Marketing to different Asian communities: The importance of culture for framing advertising messages, and for purchase intent. Asia Pacific Journal of Marketing and Logistics, $25(1), 8-33$.

McCarthy, E. J. (1965). E. Jerome McCarthy. The Concept of the Marketing Mix.

Munadi, M., \& Iswanto, B. (2020). The Concept Maslahah of Najamuddin al Tufi and It's Relevance of Sharia Business. IQTISHODUNA: Jurnal Ekonomi Islam.

Purnama, F. A., \& Safira, A. (2017). Investigating Islamic advertising ethics: Perceptions of Indonesian Muslims. Journal of Emerging Economies \& Islamic Research, 5(2).

Rahman, S. S. A., Shamsudin, S. M., \& Nadzri, S. (2016). Promoting employee motivation using self-control concept from Islamic perspectives. In Proceeding of the $2^{\text {nd }}$ International Conference on Economics and Banking 2016, 356-361.

Saeed, M., \& Baig, A. K. (2013). Islamic Shari'ah-compliant marketing. International Journal of Social Entrepreneurship and Innovation 2, 2(2), 166-178.

Saeed, M., Ahmed, Z. U., \& Mukhtar, S. M. (2001). International marketing ethics from an Islamic perspective: a valuemaximization approach. Journal of Business Ethics, 32(2), 127-142.

Shamsudin, S. M., \& Rahman, S. S. A. (2014). The differences between Islamic marketing and conventional marketing: A review of the literature. In Proceeding of the 1st international conference on management and muamalah 2014 ( $1^{\text {st }}$ ICoMM), 298-307.

Shaw, M. J., Subramaniam, C., Tan, G. W., et al. (2001). Knowledge management and data mining for marketing. Decision Support Systems, 1(31), 127-137.

Shyam, S. (2017). https://www.quora.com/What-is-the-revenue-model-of-multi-level-marketing-or-network-marketingcompanies-how-are-they-making-profits-and-how-could-they-give-such-huge-returns-to-the-investors-for-such-along-time

Siahaan, E., \& ., Y. C. M. (2014). A Career Success of the Distributors in Multi-Level Marketing (MLM) Company. Information Management and Business Review, 6(6), 309-316.

Sparks, J. R., \& Schenk, J. A. (2001). Explaining the effects of transformational leadership: an investigation of the effects of higher-order motives in multilevel marketing organizations. Journal of Organizational Behavior: The International Journal of Industrial, Occupational and Organizational Psychology and Behavior, 22(8), 849-869.

Tarmudi, Z. H. (2009). Fuzzy hybrid multi-criteria decision making model for municipal solid waste disposal selection (Doctoral dissertation, Fakulti Sains dan Teknologi).

Taylor, J. M. (2000). When should an MLM or network marketing* program be considered an illegal pyramid scheme. Consumer Awareness Institute, 18.

Tameme, M., \& Asutay, M. (2012). An empirical inquiry into marketing Islamic mortgages in the UK. International Journal 
of Bank Marketing, 30(3), 150-167.

Tapp, A., \& Spotswood, F. (2013). From the 4Ps to COM-SM: Reconfiguring the social marketing mix. Journal of Social Marketing, 3(3), 206-222.

Tybout, A. M., \& Zaltman, G. (1974). Ethics in marketing research: Their practical relevance. Journal of Marketing Research, 11(4), 357-368.

Varey, R. J., \& Lewis, B. R. (Eds.). (2000). Internal marketing: Directions for management. Psychology Press.

Vassileva, B. (2017). Marketing 4.0: How technologies transform marketing organization. Obuda University e-Bulletin, $7(1), 47$. 